\title{
Synthesis and Properties of Crosslinked Polycarbosilanes by Hydrosilylation Polymerization
}

\author{
Manabu Tsumura and Takahisa Iwahara \\ Kobe Laboratories, Research Institute, Kaneka Corporation, \\ 1-2-80, Yoshida-cho, Hyogo-ku, Kobe 652-0872, Japan
}

(Received November 6, 1998)

\begin{abstract}
The aim of this investigation is the development of crosslinked polycarbosilanes (PCSs) with excellence on mechanical properties. Crosslinked polycarbosilanes were obtained by using a hydrosilylation curing reaction between multi-functional vinylsilanes and hydrosilanes. The PCSs were prepared with a casting method from the monomer solution. The mechanical properties and the glass transition temperatures $\left(T_{\mathrm{g}} \mathrm{s}\right)$ of the PCSs were measured by a flexural test and Differential Scanning Calorimetry (DSC). ${ }^{29} \mathrm{Si}$ solid-state NMR spectroscopy was employed for estimating the conversion of the vinylsilanes. The effects of the following three points on the mechanical properties of the crosslinked PCSs were evaluated: (1) the molecular weight between the crosslinking points, (2) the introduction of flexural units, and (3) the network chain density. The mechanical properties and $T_{\mathrm{g}} \mathrm{s}$ of the PCSs were found to be dependent on the structures of the monomer used. It was clear that both the high network chain density and the rigid-rod unit, $\left[-\mathrm{Me}_{2} \mathrm{Si}-p-\mathrm{C}_{6} \mathrm{H}_{4}-\mathrm{Me}_{2} \mathrm{Si}-\mathrm{CH}_{2} \mathrm{CH}_{2}-\right.$, are favorable to high mechanical properties. The improvement in strength can be related to the structures of vinylsilanes and hydrosilanes used.
\end{abstract}

KEY WORDS Polycarbosilane / Crosslinked Polymer / Hydrosilylation Cure / ${ }^{29}$ Si Solid-State Nuclear Magnetic Resonance / Network Chain Density / Mechanical and Thermal Property / Rigid-Rod Polymer /

Much attention has been focused on the structure and properties of polycarbosilanes (PCSs), which contain $\mathrm{Si}-\mathrm{C}$ bonds in polymer backbones. ${ }^{1-3}$ Furthermore, PCSs are of considerable practical concern as well. In industry, polycarbosilanes created by the thermal isomerizing of poly(dimethylsilylene) are pyrolyzed to produce Nicalon ${ }^{\mathrm{TM}}$, which is a $\mathrm{SiC}$ fiber. ${ }^{4}$ Poly(silyleneethynylenephenyleneethynylene)s $[-\mathrm{Si}(\mathrm{R}) \mathrm{H}-\mathrm{C} \equiv \mathrm{C}-$ $\left.\mathrm{C}_{6} \mathrm{H}_{4}-\mathrm{C} \equiv \mathrm{C}-\right]$ were recently reported to be used as heat-resistant polymers ${ }^{5}$ and poly(silmethylene)-based polymers as liquid crystal polymers ${ }^{6}$.

There have been various investigations into methods of synthesizing polycarbosilanes, which are a ringopening polymerization of strained monomers ${ }^{7}$, a polymerization via Grignard reaction ${ }^{8}$ and a hydrosilylation polymerization. Hydrosilylation polymerization has been reported as a well-known reaction leading to polycarbosilanes and related polymers. ${ }^{9-12}$ Recently, the authors have reported on the synthesis and properties of linear PCSs produced by means of a hydrosilylation polymerization. ${ }^{13,14}$

Crosslinked polycarbosiloxanes have been investigated by Hadziioannou's group. ${ }^{15,16}$ They prepared polycarbosiloxanes by hydrosilylation reaction and evaluated the mechanical properties. Hyperbranched polycarbosilanes ${ }^{17}$ and dendritic polycarbosilanes ${ }^{18,19}$ were synthesized by hydrosilylation reaction. The synthesis and application of crosslinked PCSs have been reported by Friedmann. ${ }^{20}$ Here, they used a hydrosilylation reaction as the synthetic method and various carbon-based compounds as monomers which have vinyl groups. Very little work is currently available, however, on the synthesis and mechanical properties of crosslinked PCSs. More recently, the authors reported the synthesis and properties of the crosslinked PCSs by a hydrosilylation reaction of multifunctional $\mathrm{Si}-$ vinyl and $\mathrm{Si}-\mathrm{H}$ monomers. ${ }^{21}$ The crosslinked PCS (Scheme 1, PCS A) obtained from a hydrosilylation between compounds (1) and (2) possessed good thermal properties, but the value of maximum flexural strength of the PCS, 47.4 MPa, was too low to use the PCS as structural materials. The purpose of this work is to obtain PCSs with improved mechanical properties.

\section{EXPERIMENTAL}

\section{Materials}

PCS monomers, 1,4-bis(dimethylvinylsilyl)benzene (1), 1,3,5,7-tetramethylcyclotetrasiloxane (2), 1,4-bis(dimethylsilyl)benzene (3), 1,3-divinyl-1,1,3,3-tetramethyldisiloxane (4), methylphenyldivinylsilane (5), 1,3,5trimethyl-1,3,5-trivinylcyclotrisiloxane (6), tetravinylsilane (7), 1,3,5,7-tetramethyl-1,3,5,7-tetravinylcyclotetrasiloxane (8), phenylsilane (10), methylphenylsilane (11), were purchased from Shin-Etsu Chemical Co., Ltd. 1,3,5-Tris(dimethylsilyl)benzene (9) was synthesized according to the methods previously reported. ${ }^{22}$ The platinum catalyst $\left[\mathrm{Pt}\left\{\left(\mathrm{CH}_{2}=\mathrm{CHSiMe}\right)_{2} \mathrm{O}_{2}\right](1.0 \mathrm{wt} \%\right.$ xylene solution) was prepared through the reaction of $\mathrm{H}_{2} \mathrm{PtCl}_{6} \cdot 6 \mathrm{H}_{2} \mathrm{O}$ and 1,1,3,3-tetramethyl-1,3-divinyldisiloxane. ${ }^{23.24}$ Dimethyl maleate (TOKYO KASEI Co., Ltd.) and tetrahydrofuran (Nacalai Tesque Co., Ltd.) were used without further treatment.

\section{Preparation of Crosslinked PCS (Table IV, Sample No. 1 as an Example)}

Monomer (1) $(2.97 \mathrm{~g}, 12.0 \mathrm{mmol})$, monomer (9) (2.03 g, $8.0 \mathrm{mmol}$ ), $10 \mathrm{wt} \%$ tetrahydrofuran (THF) solution of dimethyl maleate $(32 \mathrm{mg})$, and the Pt catalyst $(5.0 \mathrm{mg}$, $\left.9.71 \times 10^{-5} \mathrm{mmol} \mathrm{mg}^{-1}\right)$ were dissolved in THF $(2 \mathrm{~mL})$. The can was then covered with a lid and placed in an oven at $50^{\circ} \mathrm{C}$ for $16 \mathrm{~h}$, additionally heated stepwise $\left(80^{\circ} \mathrm{C} / 9 \mathrm{~h} \rightarrow 100^{\circ} \mathrm{C} / 16 \mathrm{~h} \rightarrow 150^{\circ} \mathrm{C} / 24 \mathrm{~h}\right)$. The cured sample obtained (1.2 mm thickness) was transparent. Its gel content was $92 \%$. Gel content was measured by the following procedure: A piece of cured specimen ( $c a$. 
$200 \mathrm{mg}$ ) wrapped in a stainless steel net was immersed in THF (ca. $200 \mathrm{~mL}$ ) for $12 \mathrm{~h}$. The gel content here was defined as the residual weight ratio of a sample after dipping and drying $\left(100^{\circ} \mathrm{C} / 4 \mathrm{~h}\right)$. The other crosslinked PCS samples were prepared in the similar manner as described above.

\section{Measurements}

${ }^{29} \mathrm{Si}$ NMR measurements were made using a Bruker AMX-400 spectrometer. The high-resolution solid-state ${ }^{29} \mathrm{Si}$ NMR spectra were obtained by the combined use of dipolar-decoupling (DD) and magic-angle spinning (MAS). ${ }^{25.26}$ The spinning frequency was about $5.0 \mathrm{kHz}$. Mechanical data were collected from flexural bars $(4.0 \times$ $0.7 \times \sim 0.14 \mathrm{~cm}$ ) made from cured film in a Shimadzu AUTO-GRAPH with maximum load cell of $100 \mathrm{~kg}$, and a cross-head speed of $0.9 \mathrm{~mm} \mathrm{~min}^{-1}$ was used for all flexural analysis (JIS K 7203). The specimen was cut from the cured sample by a cutter with a diamond-blade. DSC (Differential scanning calorimetry) was performed with a DSC-50 Shimadzu thermal analyzer at heating rates of $20^{\circ} \mathrm{C} \mathrm{min}-1$.

\section{RESULTS AND DISCUSSION}

The crosslinked PCSs have been prepared by using a hydrosilylation curing reaction between multi-functional vinylsilanes and hydrosilanes. The effects of following three points on the mechanical properties of the crosslinked PCSs were evaluated: (1) the molecular weight between the crosslinking points, (2) the introduction of flexural units, and (3) the network chain density.

\section{Effects of the Molecular Weight between the Crosslinking Points}

There are several ways to evaluate the molecular weight between the crosslinking points. At first, the prepolymer having vinyl functionalities was prepared and then crosslinked with reactive silicon-hydrogen groups. However, the linear PCS oligomer, which was caused to react between the monomers (1) and (3), was insoluble in common organic solvents. ${ }^{13}$ Therefore, the crosslinked PCS via in situ chain extending and crosslinking reaction of the PCS monomers (1), (3), and the crosslinking agent (2) were synthesized (Scheme 1, PCS B). The curing reaction was performed with a casting method heating stepwise $\left(50 / 80 / 100 / 150^{\circ} \mathrm{C}\right)$. In this case, the casting sample was the THF solution of the PCS monomers and Pt catalyst. Table I shows the appearance, glass transition temperatures $\left(T_{\mathrm{g}} \mathrm{s}\right)$ and gel contents of PCS B varying the molar ratio of $1 / 2 / 3$. The number of units $(n)$ is calculated by the molar ratio of $1 / 3$. In the case of No. $2-5$ in Table I, the structure between the crosslinking points (2) was formally illustrated as Figure 1. In actually, however, the structure was very complex one. The transparency, $T_{\mathrm{g}} \mathrm{s}$ and gel contents, illustrated in Table $I$, are seen to decrease with an increase in the number of repeating units $(n)$. The decrease in transparency was presumed to be owing to the high crystallinity of polymer backbones. Table II shows the relation between the number of repeating units $(n)$ and the tensile properties. Both the tensile modulus and maximum tensile strength were inversely proportional to the number of repeating units $(n)$ - the molecular weight between the crosslinking points. The same trend was reported in the crosslinked polycarbosiloxanes. ${ }^{16}$ This result indicates that the high molecular weight between the crosslinking points have no effect on the improvement of mechanical properties of crosslinked polycarbosilanes.

\section{Effects of the Introduction of Flexural Units}

$\mathrm{Si}$-vinyl monomers having flexible units were used to obtain a tough material. Monomers (4) and (5) were used as the flexible monomers (Scheme 1, (3), (4)). PCS C and

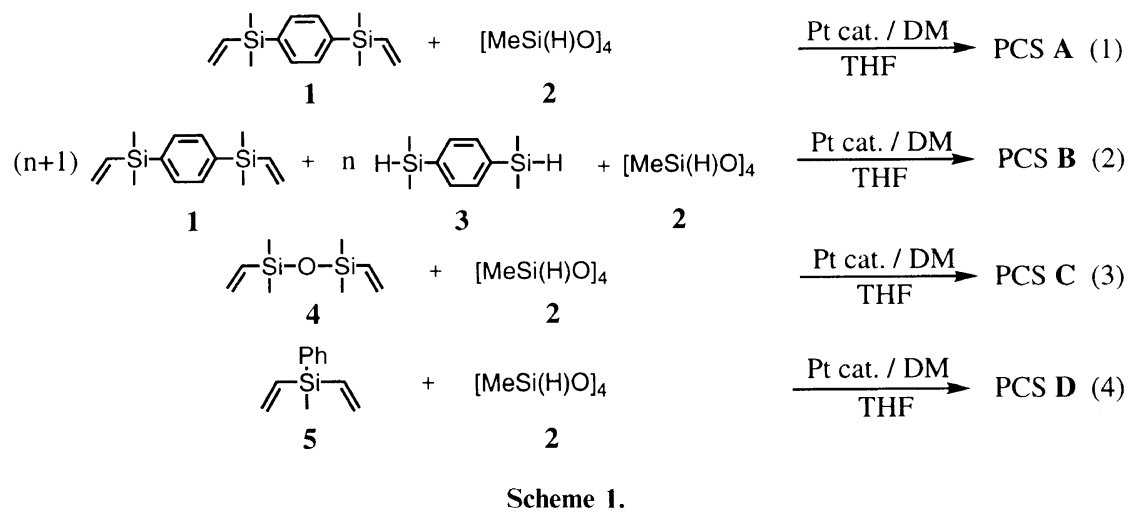

Table I. Preparation of a series of PCS Bs ${ }^{\mathrm{a}}$

\begin{tabular}{|c|c|c|c|c|c|c|c|}
\hline \multirow{2}{*}{ No. } & \multirow{2}{*}{$\begin{array}{c}\text { Number of } \\
\text { units }(n)\end{array}$} & \multicolumn{3}{|c|}{ Amounts of monomers, $\mathrm{g} / \mathrm{mmol}$} & \multirow{2}{*}{ Appearance } & \multirow{2}{*}{$T_{\mathrm{g}} / \mathrm{C}^{\mathrm{b}}$} & \multirow{2}{*}{$\frac{\text { Gel conten }}{\%}$} \\
\hline & & 1 & 2 & 3 & & & \\
\hline 1 & 1 & $3.50(14.2)$ & $1.71(7.10)$ & $0.00(0.00)$ & Transparent & 85.3 & 100 \\
\hline 2 & 3 & $3.05(12.4)$ & $0.75(3.10)$ & $1.22(6.30)$ & Translucent & 31.9 & 96.9 \\
\hline 3 & 5 & $2.88(11.7)$ & $0.47(1.96)$ & $1.52(7.80)$ & Translucent & 25.9 & 92.8 \\
\hline 4 & 9 & $3.00(12.1)$ & $0.29(1.20)$ & $1.88(9.70)$ & Opaque & - & 84.1 \\
\hline 5 & 19 & $2.80(11.4)$ & $0.14(0.58)$ & $2.00(10.3)$ & Opaque & - & 83.7 \\
\hline
\end{tabular}

${ }^{a}$ Curing conditions: $50^{\circ} \mathrm{C} / 16 \mathrm{~h} \rightarrow 80^{\circ} \mathrm{C} / 9 \mathrm{~h} \rightarrow 100^{\circ} \mathrm{C} / 16 \mathrm{~h} \rightarrow 150^{\circ} \mathrm{C} / 24 \mathrm{~h}$, Pt cat.; $1.0 \times 10^{-5}$ molar equivalent rel. to the vinyl substituents. ${ }^{\mathrm{b}}$ By DSC. 


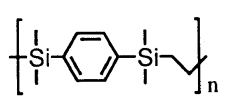

Figure 1. Repeating unit of PCS B
Table II. Tensile properties of PCS B

\begin{tabular}{|c|c|c|c|c|}
\hline \multirow{2}{*}{ No. } & \multirow{2}{*}{$\begin{array}{c}\text { Number of } \\
\text { units }(n)\end{array}$} & $\begin{array}{l}\text { Tensile } \\
\text { modulus }\end{array}$ & $\begin{array}{l}\text { Tensile } \\
\text { strength }\end{array}$ & $\begin{array}{l}\text { Maximum } \\
\text { elongation }\end{array}$ \\
\hline & & $\mathrm{GPa}$ & $\mathrm{MPa}$ & $\%$ \\
\hline 1 & 1 & 0.99 & 27.9 & 5.9 \\
\hline 2 & 3 & 1.00 & 13.2 & 53.8 \\
\hline 3 & 5 & 0.59 & 8.2 & 25.9 \\
\hline
\end{tabular}

Table III. Properties of PCS C and PCS D

\begin{tabular}{|c|c|c|c|c|c|c|}
\hline & \multirow{2}{*}{ Appearance } & \multirow{2}{*}{$T_{\mathrm{g}} /{ }^{\circ} \mathrm{C}^{\mathrm{a}}$} & \multirow{2}{*}{$\frac{\text { Gel content }}{\%}$} & \multirow{2}{*}{$\frac{\text { Tensile modulus }}{\mathrm{GPa}}$} & \multirow{2}{*}{$\frac{\text { Tensile strength }}{\mathrm{MPa}}$} & \multirow{2}{*}{$\frac{\text { Maximum elongation }}{\%}$} \\
\hline & & & & & & \\
\hline PCS C & Transparent & 2.7 & 100 & 0.002 & 3.9 & 3.1 \\
\hline PCS D & Transparent & 15.2 & 93.1 & 0.005 & 2.8 & 45.6 \\
\hline
\end{tabular}

${ }^{\mathrm{a}}$ By DSC.

PCS D was transparent and leather-like materials which $T_{\mathrm{g}} \mathrm{s}$ were below r.t. (Table III). The tensile modulus and maximum tensile strength of both PCSs were smaller than those of PCS A (sample No. 1 in Table II). As a result, it was clear that the bis(dimethylsilylene)- $p$ phenylene unit $\left[\mathrm{Si}(\mathrm{Me})_{2}-p-\mathrm{C}_{6} \mathrm{H}_{4}-\mathrm{Si}(\mathrm{Me})_{2}\right]$ was important for improving the mechanical properties of the crosslinked PCS.

\section{Effects of the Crosslink Density}

The effects of the crosslink density on mechanical strengths were evaluated. These are the structures of $\mathrm{Si}-$-vinyl monomers and $\mathrm{Si}-\mathrm{H}$ monomers used in Figures 2 and 3 , respectively. Table IV summarizes the recipe for the preparation of various PCSs. Platinum divinyltetramethyldisiloxane as a hydrosilylation catalyst and dimethyl maleate (DM) as a retarder of a hydrosilylation reaction were used. In the case of using monomer (7) as a $\mathrm{Si}$-vinyl monomer, hydrosilylation reaction was so exothermic that the reaction mixture quickly turned to gel with at the conventional concentration of the catalyst and retarder $\left(\mathrm{Pt}\right.$ cat.: $1.0 \times 10^{-5}$ eq. rel. to the $\mathrm{Si}-$ vinyl groups, [DM]: 100 eq. rel. to Pt cat.). The reason for this would be that the steric hindrance around the silicon atom of monomer (7) is less than that of the other $\mathrm{Si}-$ vinyl monomers (1), (6), and (8). Using 500 equiv. of dimethylmaleate to Pt cat., the crosslinked PCSs proved to be transparent material without bubbles and cracks (Table IV, Nos. 4, 6). Table V shows the appearance and gel contents of the crosslinked PCSs obtained. The crosslinked PCS (sample No. 1) was leather-like and the gelation did not proceed perfectly. On the contrary, the other crosslinked PCSs were rigid materials and the gel contents were almost $100 \%$. These results suggest that steric hindrance around the silyl groups of monomer (9) prevents the hydrosilylation curing reaction from proceeding perfectly.

To obtain more information on the hydrosilylation curing reaction, the ratio of the conversion of $\mathrm{Si}-\mathrm{vinyl}$ groups was estimated with ${ }^{29} \mathrm{Si} \mathrm{DD} / \mathrm{MAS}$ NMR spectroscopy. Figure 4 provides ${ }^{29} \mathrm{Si} \mathrm{DD} / \mathrm{MAS}$ NMR spectra of crosslinked PCS of No. 1 and No. 4 in Table V, and Table VI summarizes the ${ }^{29} \mathrm{Si}$ chemical shifts of PCS

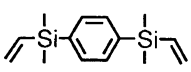

1

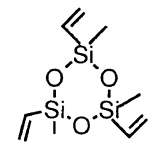

6

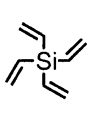

7

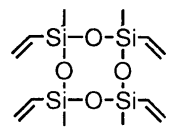

8
Figure 2. The PCS monomers which have Si vinyl groups.

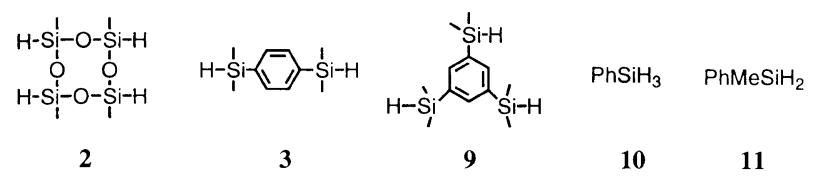

Figure 3. The PCS monomers which have $\mathrm{Si}-\mathrm{H}$ groups.

Table IV. Recipe for preparation of PCSs with various crosslinking densities ${ }^{\mathrm{a}}$

\begin{tabular}{|c|c|c|c|c|}
\hline \multirow{2}{*}{ No. } & \multicolumn{2}{|c|}{ Amounts of PCS monomers, $\mathrm{g} / \mathrm{mmol}^{\mathrm{b}}$} & \multirow{2}{*}{$\begin{array}{l}\text { Pt cat. } \\
\left(\times 10^{-5}\right)\end{array}$} & \multirow{2}{*}{$\mathrm{DM}^{\mathrm{c}}$} \\
\hline & Si-vinyl & $\mathrm{Si}-\mathrm{H}$ & & \\
\hline 1 & $\mathbf{1}, 2.97(12.0)$ & 9, $2.03(8.00)$ & 2.0 & 100 \\
\hline 2 & 6, $2.35(9.10)$ & $3,2.64(13.7)$ & 1.0 & 100 \\
\hline 3 & $1,3.50(14.2)$ & $2,1.71(7.10)$ & 1.0 & 100 \\
\hline 4 & $7,1.30(9.52)$ & $3,3.70(19.0)$ & 0.5 & 500 \\
\hline 5 & $8,2.34(6.80)$ & $3,2.64(13.6)$ & 1.0 & 100 \\
\hline 6 & $7,1.45(10.6)$ & $9,3.57(14.1)$ & 0.5 & 500 \\
\hline 7 & $8,2.53(7.35)$ & 9, $2.48(9.80)$ & 1.0 & 100 \\
\hline
\end{tabular}

a Curing conditions: $50^{\circ} \mathrm{C} / 16 \mathrm{~h} \rightarrow 80^{\circ} \mathrm{C} / 9 \mathrm{~h} \rightarrow 100^{\circ} \mathrm{C} / 16 \mathrm{~h} \rightarrow 150^{\circ} \mathrm{C} / 24 \mathrm{~h}$. ${ }^{\mathrm{b}} \mathrm{Si}-\mathrm{vinyl} / \mathrm{Si}-\mathrm{H}=1 / 1 \quad(\mathrm{~mol}) .{ }^{\mathrm{c}} \operatorname{Pt}\left[\left(\mathrm{CH}_{2}=\mathrm{CHMe}_{2} \mathrm{Si}\right)_{2} \mathrm{O}\right]_{3}$, the molar equivalent rel. to the vinyl substituents. ${ }^{\mathrm{d}}$ Relative amount of dimethylmaleate (DM) to the Pt catalyst.

Table V. Properties of the crosslinked PCSs

\begin{tabular}{|c|c|c|c|c|c|}
\hline \multirow{2}{*}{ No. } & \multicolumn{2}{|c|}{ PCS monomers } & \multirow{2}{*}{ Appearance ${ }^{a}$} & \multirow{2}{*}{$\frac{\text { Gel content }}{\%}$} & \multirow{2}{*}{$\begin{array}{c}\text { Conversion } \\
\text { - of } \mathrm{Si}-\mathrm{viny} / \\
\% \mathrm{~b}\end{array}$} \\
\hline & Si-vinyl & $\mathrm{Si}-\mathrm{H}$ & & & \\
\hline 1 & 1 & 9 & Leather-like, TP & 92 & 85 \\
\hline 2 & 6 & 3 & Rigid, TP & 99 & 100 \\
\hline 3 & 1 & 2 & Rigid, TP & 100 & 95 \\
\hline 4 & 7 & 3 & Rigid, TP & 100 & 95 \\
\hline 5 & 8 & 3 & Rigid, TP & 99 & - \\
\hline 6 & 7 & 9 & Rigid, TP & 100 & 92 \\
\hline 7 & 8 & 9 & Rigid, TP & 100 & 93 \\
\hline
\end{tabular}

${ }^{\text {a }} \mathrm{TP}$; transparent. b ${ }^{29} \mathrm{Si}$ solid-state NMR analysis. 
(a)

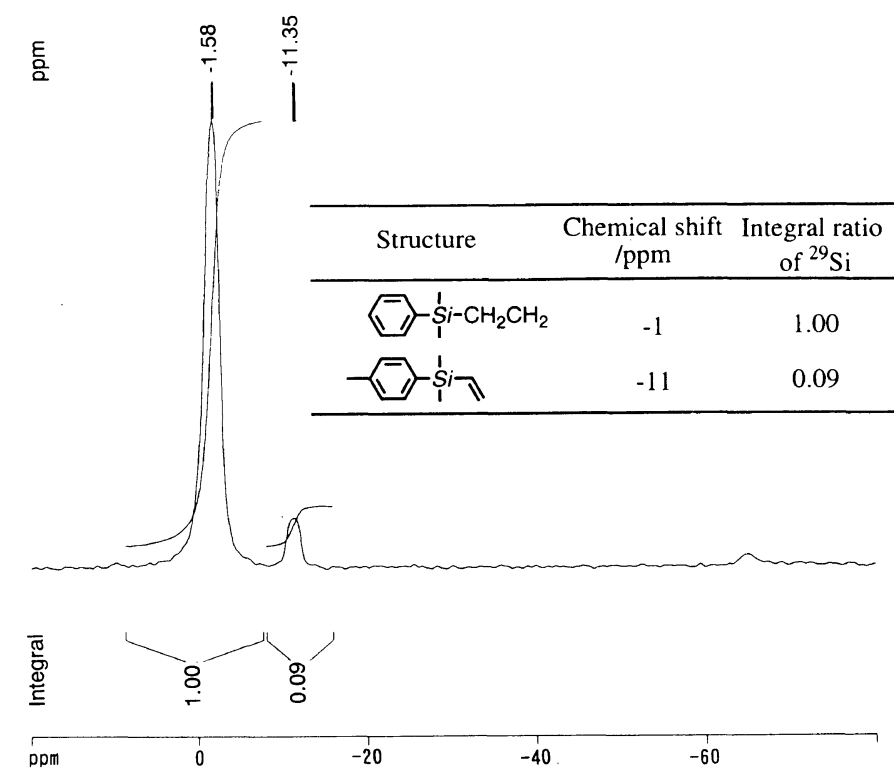

(b)

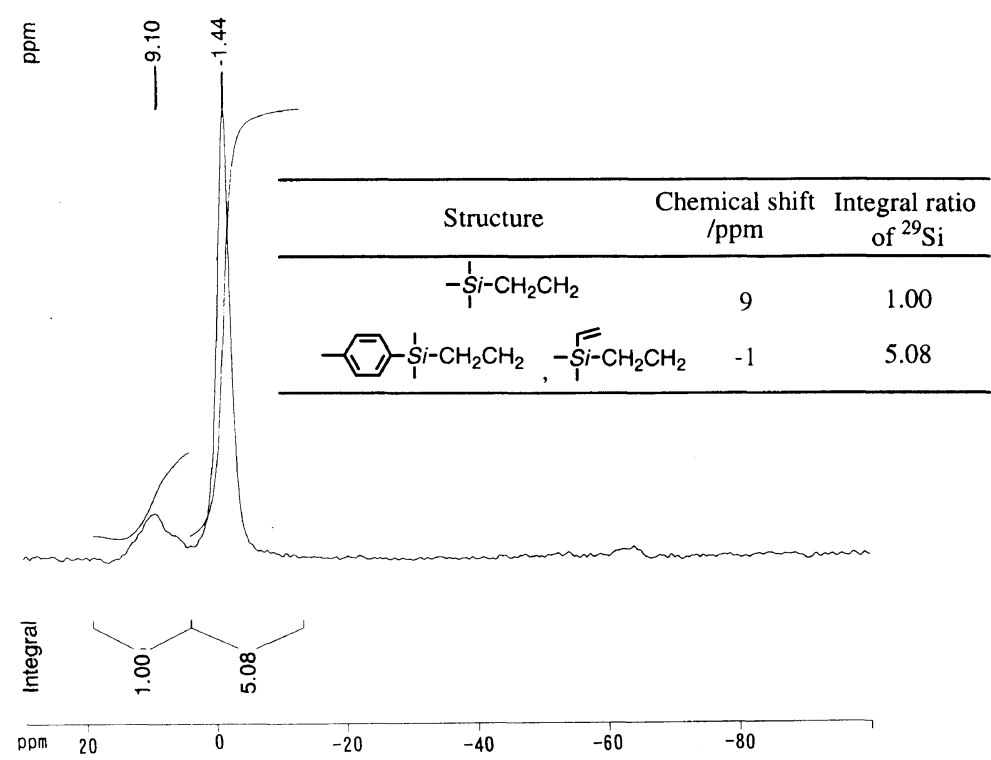

Figure 4. ${ }^{29} \mathrm{Si} \mathrm{DD} / \mathrm{MAS}$ spectra of (a) sample No. 1 and (b) sample No. 4 in Table V, respectively.

Table VI. ${ }^{29} \mathrm{Si} \mathrm{NMR}$ chemical shifts of the monomers ${ }^{\mathrm{a}}$

\begin{tabular}{ccc}
\hline No. & PCS monomer & ${ }^{29} \mathrm{Si} \delta / \mathrm{ppm}$ \\
\hline 1 & $\mathbf{1}$ & -10.8 \\
2 & $\mathbf{6}$ & -22.4 \\
3 & $\mathbf{7}$ & -26.2 \\
4 & $\mathbf{8}$ & -32.5 \\
5 & $\mathbf{9}$ & -16.4 \\
6 & $\mathbf{3}$ & -16.8 \\
7 & $\mathbf{2}$ & -32.3 \\
\hline
\end{tabular}

${ }^{a}{ }^{29} \mathrm{Si}$ solid-state NMR analysis without spinning.

monomers used. In a spectrum (a) of Figure 4 for sample No. 1 , two resonances at -1 and -11 ppm would be assignable to the hydrosilylated structure of both monomers and unreacted monomer (1), respectively. From the integral ratio, the conversion of $\mathrm{Si}-$-vinyl groups was calculated $c a .85 \%(=0.5 / 0.59 \times 100)$. From the ${ }^{29} \mathrm{Si}$
TableVII. ${ }^{29} \mathrm{Si}$ NMR chemical shifts of the standard samples

\begin{tabular}{ccc}
\hline No. & Sample name & ${ }^{29} \mathrm{Si} \delta / \mathrm{ppm}$ \\
\hline 1 & $\left(\mathrm{CH}_{3}\right)_{4} \mathrm{Si}$ & 1.00 \\
2 & $\left(\mathrm{CH}_{3}\right)_{3} \mathrm{SiCH}=\mathrm{CH}_{2}$ & -7.60 \\
3 & $\left(\mathrm{CH}_{3}\right)_{2} \mathrm{Si}\left(\mathrm{CH}=\mathrm{CH}_{2}\right)_{2}$ & -13.67 \\
4 & $\left(\mathrm{CH}_{3}\right) \mathrm{Si}\left(\mathrm{CH}=\mathrm{CH}_{2}\right)_{3}$ & -20.55 \\
5 & $\left(\mathrm{C}_{2} \mathrm{H}_{5}\right)_{4} \mathrm{Si}$ & 8.40 \\
6 & $\left(\mathrm{C}_{2} \mathrm{H}_{5}\right)_{3} \mathrm{SiCH}=\mathrm{CH}_{2}$ & -1.70 \\
\hline
\end{tabular}

DD/MAS NMR analysis, it was clear that the hydrosilylation reaction did not proceed completely. Table $\mathrm{V}$ summarizes the percentage of hydrosilylated $\mathrm{Si}-$ vinyl groups estimated in a similar manner. In the case of using compound (9) as a $\mathrm{Si}-\mathrm{H}$ monomer (sample Nos. 1, 6, and 7), the percentage of hydrosilylated Si-vinyl groups was less than that of the other crosslinked PCSs. These results suggest that steric hindrance of monomer (9) 
prevents the hydrosilylation curing reaction from proceeding perfectly. Next, the reaction of monomer (7) will be discussed. Table VII summarizes the ${ }^{29} \mathrm{Si}$ chemical shifts of standard samples. ${ }^{27}$ In a spectrum (b) of Figure 4 for sample No. 4 , the resonances at $9 \mathrm{ppm}$ would be assignable to the completely hydrosilylated structure of monomer (7). If the hydrosilylation curing reaction between monomers (7) and (3) proceeded perfectly, the integral ratio of the signals at $9 \mathrm{ppm} / \mathrm{at}-1 \mathrm{ppm}$ would be $1 / 4$. However the actual integral ratio was $1 / 5$. This indicated that the hydrosilylation curing reaction did not proceed perfectly. Figure 5 illustrates the possible structure obtained with the hydrosilylation curing reaction between monomers (7) and (3).

The relationship between the structures and mech- anical properties of the crosslinked PCSs will be discussed. Table VIII summarizes the $T_{\mathrm{g}} \mathrm{s}$ and flexural properties of the crosslinked PCSs in Table IV. Generally the $T_{\mathrm{g}}$ of crosslinked PCS increased as the sum of the number of $\mathrm{Si}-$-vinyl and $\mathrm{Si}-\mathrm{H}$ groups increased. It was reported that $T_{\mathrm{g}}$ increased in low motility of the macromolecular chain. ${ }^{16}$ The low motility would depend on the rigidity of the macromolecular chain and the network chain density. In the comparison of sample Nos. 2,4 , and 5 , in the case of using monomer (3) as a $\mathrm{Si}-\mathrm{H}$ monomer, the $T_{\mathrm{g}}$ of sample No. 4 was the highest. The lower $T_{\mathrm{g}} \mathrm{s}$ of sample Nos. 2 and 5 are considered to be due to the introduction of the highly flexible of the siloxy units. Furthermore, the $T_{\mathrm{g}}$ of sample No. 6 was $145.3^{\circ} \mathrm{C}$ and that of sample No. 7 was undetectable. It was clear
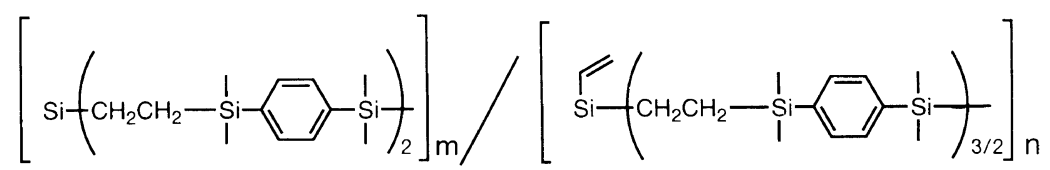

$\mathrm{m} / \mathrm{n}=1 / 0.27$

Figure 5. Possible structure of the crosslinked PCS (sample No. 4 in Table V).

Table VIII. $T_{\mathrm{g}} \mathrm{s}$ and flexural properties of crosslinled PCSs

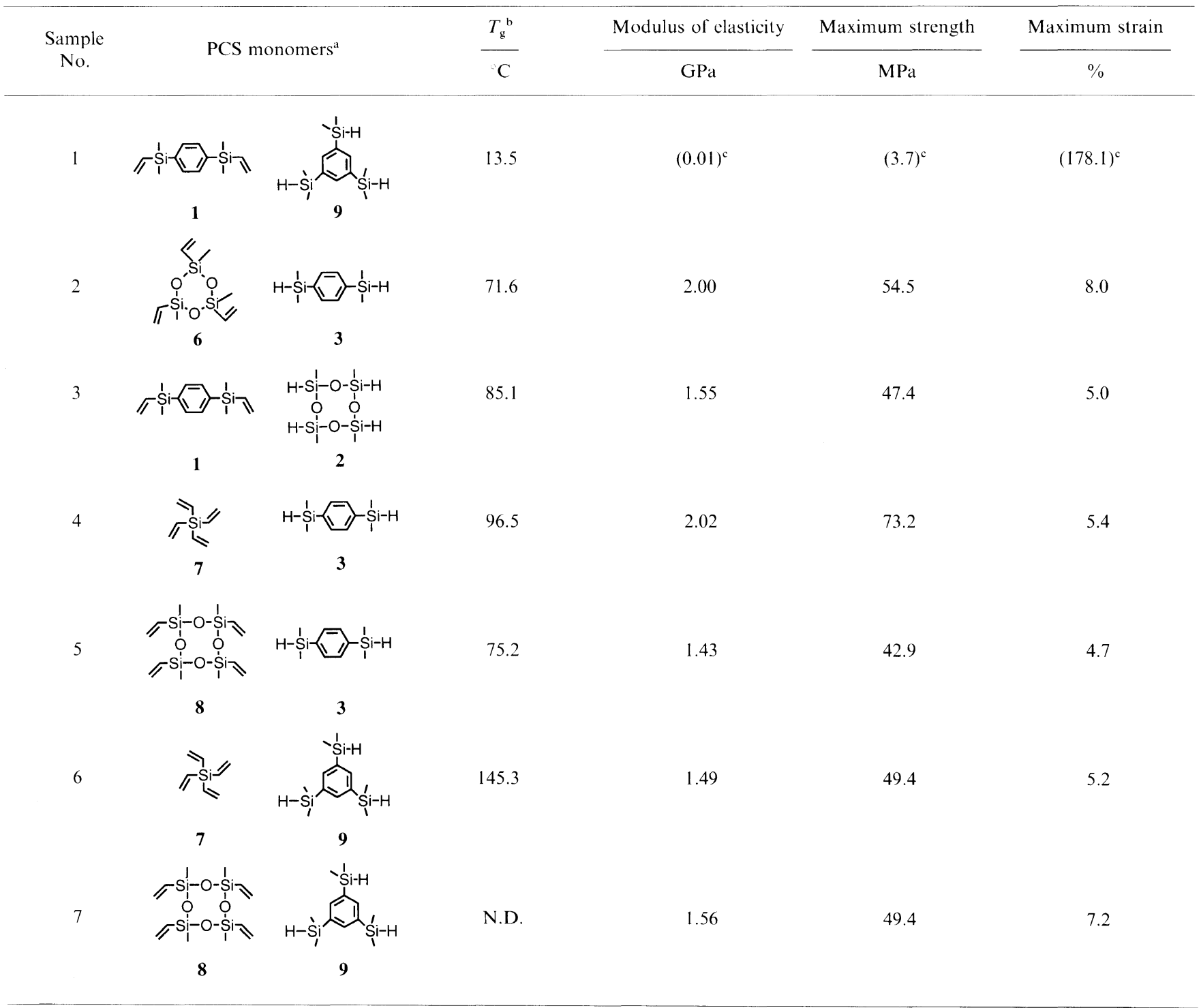

${ }^{a} \mathrm{Si}-\mathrm{vinyl} / \mathrm{Si}-\mathrm{H}=1 / 1(\mathrm{~mol}) .{ }^{\mathrm{b}} \mathrm{DSC}$ analysis. ${ }^{\mathrm{c}}$ Tensile mode. 
Table IX. The appearance and flexural properties of some crosslinked PCSs prepared from monomer 7

\begin{tabular}{|c|c|c|c|c|c|c|c|}
\hline \multirow{2}{*}{ No. } & \multicolumn{2}{|c|}{ Amounts of PCS monomers, $\mathrm{g} / \mathrm{mmol}^{\mathrm{a}}$} & \multirow{2}{*}{ Appearance $^{b}$} & \multirow{2}{*}{$\frac{\text { Gel content }}{\%}$} & \multirow{2}{*}{$\begin{array}{c}\begin{array}{c}\text { Modulus of } \\
\text { elasticity }\end{array} \\
\text { GPa }\end{array}$} & \multirow{2}{*}{$\frac{\begin{array}{c}\text { Maximum } \\
\text { strength }\end{array}}{\mathrm{MPa}}$} & \multirow{2}{*}{$\begin{array}{c}\begin{array}{c}\text { Maximum } \\
\text { strain }\end{array} \\
\%\end{array}$} \\
\hline & Si -vinyl & $\mathrm{Si}-\mathrm{H}$ & & & & & \\
\hline 1 & $7,1.79(13.1)$ & $11,3.20(26.2)$ & Fragile, TP & 92 & 1.26 & 37.5 & 4.7 \\
\hline 2 & $7,2.43(17.8)$ & $10,2.57(23.7)$ & Fragile, TP & 100 & $-^{\mathrm{c}}$ & $ـ^{\mathrm{c}}$ & $-^{c}$ \\
\hline 3 & $7,1.81(13.3)$ & $2,3.20(26.2)$ & Fragile, TP & 100 & $\square^{c}$ & $-^{c}$ & $\square^{c}$ \\
\hline
\end{tabular}

${ }^{\text {a }} \mathrm{Si}-\mathrm{vinyl} / \mathrm{Si}-\mathrm{H}=1 / 1 \mathrm{~mol}$ ). Curing conditions: $50^{\circ} \mathrm{C} / 16 \mathrm{~h} \rightarrow 80^{\circ} \mathrm{C} / 9 \mathrm{~h} \rightarrow 100^{\circ} \mathrm{C} / 16 \mathrm{~h} \rightarrow 150^{\circ} \mathrm{C} / 24 \mathrm{~h}$, Pt cat.; $1.0 \times 10^{-5}$ molar equivalent rel. to the vinyl substituents. ${ }^{\mathrm{b}} \mathrm{TP}$; transparent. ${ }^{\mathrm{c}}$ Too fragile to obtain the data.

that the $T_{\mathrm{g}}$ of crosslinked PCS increased as the sum of the number of $\mathrm{Si}-$-vinyl and $\mathrm{Si}-\mathrm{H}$ groups increased. On the other hand, the mechanical properties of sample No. 4 was the highest of all the PCSs. The value of flexing modulus was $2.02 \mathrm{GPa}$ and the value of maximum flexural strength was $73.2 \mathrm{MPa}$. In the case of using monomer (9) as a $\mathrm{Si}-\mathrm{H}$ monomer (sample No. 6), the mechanical properties decreased compared with those of sample No. 4. The low mechanical property is considered to be due to the meta-linkage bending unit at the crosslinking site. Furthermore, without the bis(dimethylsilylene)- $p$-phenylene unit, [ $\left.\mathrm{Si}(\mathrm{Me})_{2}-p-\mathrm{C}_{6} \mathrm{H}_{4}-\mathrm{Si}(\mathrm{Me})_{2}\right]$, the crosslinked PCSs were fragile (Table IX). It was clear that the high network chain density and a rigid-rod unit, $\left[\mathrm{Si}(\mathrm{Me})_{2}-p-\mathrm{C}_{6} \mathrm{H}_{4}-\mathrm{Si}(\mathrm{Me})_{2}\right]$ was necessary to obtain any crosslinked PCSs having high mechanical strength.

\section{CONCLUSIONS}

PCSs were prepared by using a hydrosilylation curing reaction between multi-functional vinylsilanes and hydrosilanes. The high molecular weight between the crosslinking points and the introduction of the flexible units have no effect on the improvement of mechanical properties. The high network chain density and rigid-rod unit, $\left[\mathrm{Si}(\mathrm{Me})_{2}-p-\mathrm{C}_{6} \mathrm{H}_{4}-\mathrm{Si}(\mathrm{Me})_{2}\right]$, is necessary to give high mechanical strength to crosslinked PCSs.

Acknowledgments. This work was performed by Kaneka Corporation, under the management of the Japan Chemical Innovation Institute (JCII), as part of the Industrial Science and Technology Frontier Program supported by the New Energy and Industrial Technology Development Organization (NEDO).

\section{REFERENCES}

1. C. X. Liao, M. W. Chen, L. Sun, and W. P. Weber, J. Inorg. and Organomet. Polym., 3, 231 (1993).
2. S. W. Krska and D. Seyferth, J. Am. Chem. Soc., 120, 3604 (1998).

3. T. Ogawa and M. Murakami, J. Polym. Sci., Polym. Chem., 35, 399 (1997)

4. S. Yajima, Am. Ceram. Soc. Bull., 62, 893 (1983).

5. M. Itoh, K. Inoue, K. Iwata, M. Mitszuka, and T. Kakigano, Macromolecules, 30, 694 (1997).

6. T. Ganicz, W. Stanczyk, E. Bialecka-Florjanczyk, and I. Sledzinska, Polymer, 37. 4167 (1996).

7. L. V. Interrante, Q. Liu, I. Rushkin, and Q. Shen, J. Organomet. Chem., 521, I (1996).

8. S. Ahn, Y. S. Cho, B. R. Yoo, and Il N. Jung, Organometallics, 17, 2404 (1998).

9. E. N. Znamenskaya, N. S. Nametkin, N. A. Pritula, V. D. Oppengeim, and T. I. Chernysheva, Neftekhimiva, 4, 487 (1964).

10. Y. Pang, S. Ijadi-Maghssodi, and T. J. Barton, Macromolecules, 26, 5671 (1993).

11. P. R. Dvornic and V. V. Gerov, Macromolecules, 27. 1068 (1994).

12. P. R. Dvornic, V. V. Gerov, and M. N. Govedarica, Macromolecules, 27, 7575 (1994).

13. M. Tsumura and T. Iwahara, Polym. J., 27, 1048 (1995).

14. M. Tsumura and T. Iwahara, J. Polym. Sci.. Polvm. Chem., 34. 3155 (1996).

15. T. A. C. Flipsen, R. Derks, H. Van Der Vegt, A. J. Pennings, and G. Hadziioannou, J. Polym. Sci., Polym. Chem., 35, 41 (1997).

16. T. A. C. Flipsen, R. Derks, H. Van Der Vegt, R. Stenekes, A. J. Pennings, and G. Hadziioannou, J. Polym. Sci., Polym. Phys., 35. 1311 (1997).

17. C. Kim and K. Au, J. Organomet. Chem., 547, 55 (1997).

18. L.-L. Zhou and J. Roovers, Macromolecules, 26, 963 (1993).

19. C. Lach and H. Frey, Macromolecules, 31, 2381 (1998).

20. G. Friedmann and P. S. et J. Brossas, Eur. Polym. J., 29, 1197 (1993).

21. M. Tsumura, K. Ando, J. Kotani, M. Hiraishi, and T. Iwahara, Macromolecules, 31. 2716 (1998).

22. P. Herberto, J. Organomet. Chem., 435, 21 (1992).

23. G. Chandra, P. B. Hitchcock, M. F. Lappert, and P. Y Lo, Organometallics, 6, 191 (1987).

24. P. B. Hitchcock, M. F. Lappert, and N. J. W. Warhurst, Angew. Chem. Int. Ed. Engl., 30, 438 (1991).

25. A. Pines, M. G. Gibby, and J. S. Waugh, J. Chem. Phys., 59, 569 (1973).

26. J. Schaefer, E. Stejskal, and R. Buchdahl, Macromolecules, 8, 291 (1975).

27. H. Marsmann, in "Basic Principles and Progress Oxgen-17 and Silicon-29," P. Diehl, E. Fluck, and P. Kosfeld, Ed., SpringerVerlag Berlin, Heidelberg, New York, 1981, p 125. 